\title{
Investigating Representation Ethos Émotif in 2007 French Presidential Election
}

\author{
Aprillia Firmonasari ${ }^{1}$, Rosidin Ali Syabana ${ }^{2}$ \\ Universitas Gadjah Mada, INDONESIA \\ e-mail: aprillia@ugm.ac.id ${ }^{1}$,rosidin.ali.s@mail.ugm.ac.id²
}

\begin{abstract}
The issue of immigration became prominent in French political discourse in 2005, leading to debates about France and nationalism. During the lead-up to the 2007 French Presidential election, various concepts of a French national identity were promoted by candidates: Nicolas Sarkozy, Ségolene Royal, François Bayrou, and Jean-Marie Le Pen. Candidates gave particular attention to ethos, specifically ethos émotif. In this article, the writers will discuss the ethos émotif presented by the four candidates mentioned above. The ethos will be then examined whether it was successfully embodied in these candidates' speeches by investigating the public reaction they received based on articles published in French media. This study will apply a critical discourse analysis and interactional sociolinguistics approach using elements of interaction formulated by Stébe (2008) and Kerbrat-Orecchioni (1990). Data will be examined using the software Lexico3.
\end{abstract}

Keywords: Ethos émotif; french general election political discourse.

\section{INTRODUCTION}

The 2007 French presidential election offers an interesting case for studying French political communication because during the election several concepts of national identity were voiced in response to the issue of immigration (Artufel, 2007; Dennison \& Talò, 2017; Lewis-Beck et al., 2012; Martigny, 2009; Weil, 2005). The presidential candidates glorified the concept of national identity. In their campaign speech, they questioned who the real French were (Kinsey, 1993; McKinney \& Carlin, 2004; Schäffner, 1997). This occurred because when the 2007 presidential election approached, the level of trust of French people toward President Jacques Chirac, decreased because of the increasing economic, political, social and cultural problems as a result of the arrival of immigrants to France (Barou, 2014; Bowen, 2004; Spire, 1999). These candidates used ethos émotif in their campaign speech concerning national identity. By using ethos émotif, a discourse intended to influence the emotions of audience, often through affective or polite speech, the candidates tried to increase their credibility (Auchlin, 2000, p. 75).

The twelve candidates who contested the election talked about their concept of national identity that reflected the diverse ideologies of their parties. They used a range of linguistic forms to attract public sympathy. These twelve candidates, eight men and four women, were Olivier Besancenot, José Bové, Gérard Schivardi, Marie-George Buffet, Arlette Laguiller, and Dominique Voynet of the Europe Ecology - The Greens (Europe Ecologie Les Verts/ $E E L V$ ), who focused on ecological issues; Ségolène Royal of the Socialist Party (Parti Socialiste/PS); François Bayrou of the Union for French Democracy (Union pour la Démocratie Francais/UDF); Nicolas Sarkozy of the Union for a Popular Movement (Union pour un Mouvement Populaire/UMP), and Fréderic Nihous of Hunting, Fishing, Nature and Traditions (Chasse, Pêche, Nature, Traditions/CPNT), as well as two far-rightists: Philippe De Villiers of the Movement for France (Mouvement pour la France/MPF) and Jean-Marie Le Pen of the National Front (Front National/FN) (Coulomb-Gully, 2009, p. 5).

Of these twelve candidates, only four consistently registered over $10 \%$ in the opinion polls. These included two candidates from major parties, namely, the favorites Nicolas Sarkozy (UMP) and Ségolène Royal (PS), and two candidates from smaller parties: François Bayrou (UDF), ranked third, and Jean-Marie Le Pen (FN), ranked fourth. All four candidates had long histories of political activity, either as the leaders of their parties or as candidates in the previous elections. This article focuses on these four candidates because they obtained the biggest shares of votes, 
compared to other eight candidates. Nicolas Sarkozy obtained 31.18\% shares of votes, Ségolène Royal obtained 25.87\%, François Bayrou obtained 18.57\%, and Jean-Marie Le Pen obtained $10.44 \%$. These four candidates obtained more than $10 \%$ shares of votes, while the shares of votes of the other eight candidates were between $1 \%$ ans $4 \%$. These numbers showed that the four presidential candidates had an influence that enabled them to attract people's attention. Furthermore, the four candidates also brought different ideologies. Nicolas Sarkozy was middle-rightist, Ségolène Royal was leftist (socialist), François Bayrou was middle-rightist, and Jean-Marie Le Pen was rightist (conservative). Their ideology would certainly influence their policy when they were in power (Artufel, 2007; Coulomb-Gully, 2009; Dolez \& Laurent, 2007; Mayaffre \& Scholz, 2017).

The success of the four candidates in getting the voters support was primarily due to their ability to influence the public through their campaign speeches. Each candidate used a different campaign strategy. Nicolas Sarkozy delivered a series of thematic campaign speeches, including one on the European Union in Strasbourg and one on labor law in Lille. Because of this thematic approach, Sarkozy used a range of lexical forms in his speeches (Artufel, 2007, p. 54). Conversely, Ségolène Royal used more general political speeches, and therefore exhibited less lexical diversity (Dolez \& Laurent, 2007, p. 133) Meanwhile, the centrist candidate François Bayrou gave thematic speeches that focused on public debt and education reform; as such, the lexical forms in his speeches were oriented primarily toward education, order, and authority (Aeschmann, 2008, p. 12). The final candidate, Jean-Marie Le Pen, often gave speeches that voiced 'disappointment' in French socio-political life (Marie et al., 2016; Mayer, 2013). Although many political observers suggested that Le Pen used "harsh" and even racist lexical forms, his charisma and populist rhetoric enabled him to gain significant support$10.4 \%$ of the votes (Hainsworth, 2004, p. 101).

In this article, the writers assume that when these presidential candidates produced and conveyed their messages, the public was their target audience. As such, their speech acts targeted specific goals. To create the situation they desired, they relied on specific themes, dictions, and other elements of communication - ethos (character), pathos (emotional exploitation), and logos (argumentative ability). Therefore, the questions this article wants to answere are how ethos émotif were used in speech campaign of the four candidates and in what kind of forms the ethos émotif were used (Maingueneau, 2014b, 2014a).

\section{METHODOLOGY}

As the first stage of this study, data were collected by reviewing the corpus of the political speeches delivered by the four presidential candidates in 2007 French presidential election with the goal of identifying the context of their utterances. Specific linguistic references to ethos émotif and national identity were found through two means. First, lexical tables were created using the concordancer program Lexico 3 to determine the frequency of specific linguistic elements; this software was selected because it enabled the researcher to rapidly and readily identify the lexicon and themes. From the lexical tables produced through this software, analytical tables were created to determine such elements as lexical frequency and variation (including context). These analytical tables were then elucidated and interpreted. Second, from the modules created through the first stage, the utterances and communicative strategies used by candidates in their political speeches were analyzed. Particular focus was given to the lexical variation and utterances that candidates used to discursively construct national identity; these were analyzed using critical discourse analysis.

The lexicon and expressions identified through Lexico 3 were used as the data that were analyzed using the model suggested by Van Dijk (2006, p. 117) to determine their ideological content and structure. To determine the ideological content and structure underlying candidates' expressions, an ideological scheme was created using basic categories such as social identity, activity, goals, norms, and values (with a particular focus on political parties). In the analysis, the writers took into consideration both the production side of discourse - the speakers (i.e. candidates) - and the consumption side of discourse - i.e. news item. After ascertaining the ideological contents and structures of the candidates' discourse, the writers explored how they ideologically expressed national identity in their utterances and their ethos émotif, namely, a temporal framework used in discursive situations between speakers and speech partners, which becomes the foundation of this analysis. Furthermore, the writers examined the variations and the points of departures of the said ideologies.

\section{FINDINGS AND DISCUSSION}

In this section, the writers describe the use of various ethos emotif used in four French presidential candidates in 2007. The candidates use ethos émotif in their speech in several ways, for example by using pronouns, rhetorical questions, verbs, and giving praise 
and complimentary. The writers will also describe how France media were discussed their speeches.

\section{Ethos Émotif in the Presidential Campaign}

Ethos, referring to a specific image of a speaker reflected in his or her speech, is intended to underscore the credibility, strength, and ability of the speaker (Auchlin, 2000; Maingueneau, 2014b, 2014a). A speaker's speech directly contributes to the image presented and informs the speaker's behavior and how it is interpreted. According to Baider \& Constantinou (2015, p. 5), ethos in political discourse refers to ethos émotif or emotive ethos. It is intended to influence the emotions of audience, often through affective or polite speech. Ethos émotif has three constructive elements and four destructive elements. Its constructive elements are phronesis, defining clearly what is said and known, as well as the ability to consider the pros and cons of decisions; arété, the assertion of speaker's sincerity through direct speech; and eunoia, the presentation of speaker's goodwill and willingness to listen to others. According to Barthes (1970, p. 180), a speaker must be capable of saying "follow me" (phronesis), "judge me" (arété), and "love me" (eunoia). Arété and eunoia can create sympathy, pride, and respect for the speaker, while phronesis can create empathy. However, ethos émotif also has four significant destructive elements; it may involve unjust or dishonest acts, present biased understandings of facts, involve rude or even insulting commentary, or promote intolerance (Barthes, 1970, p. 181).

Given the importance of speaking abilities in political candidacies, the French presidential candidates had to consider the elements of ethos émotif. The four main candidates in the 2007 French presidential election had distinct ways of presenting their ethos émotif. For example, on several occasions Le Pen used the phrases Sarko l'américain ("Sarko the American") and il ne se sent pas Français ("he doesn't feel French"). Such utterances were targeted at Le Pen's rival Nicolas Sarkozy, applying the destructive elements of ethos émotif to discredit him. Le Pen's utterances may be compared with those of Sarkozy, who frequently began his speeches by invoking his party's respected former leaders, such as Jacques Chaban-Delmas, Achille Peretti, Edouard Balladur, Jacques Chirac, and Alain Juppé. Sarkozy also referred to political leaders whom he considered to represent France, including Georges Mandel, Guy Moquet, Jean Moulin, and General de Gaulle. By using the names of people whom he perceived as reflecting the struggle, pride, and justice of the French people, he invoked the political consciousness of his audience. In one speech, Sarkozy stated that he was inspired to enter politics by such political figures. This example shows that Sarkozy, through his speeches, urged the public to reflect upon a part of French history, when the French took pride in their country and thought of themselves as just and dignified people. Sarkozy's used the part of the history for presenting an ethos émotif to his public. Meanwhile, in her public speeches, Ségolène Royal used more opinion-laden utterances such as c'est de penser que l'identité de la France puisse être menacée par l'immigration ("thinking that French identity can be threatened by immigration"). To strengthen her position, Royal often used the pronoun je, which means "I," to indicate that her utterances were subjective and reflected her individual sentiments. This tendency in speech differed significantly from that of François Bayrou, who consistently referred to the French people using the plural pronoun nous, which means "we.". This pronoun implies togetherness, a collective sentiment, which makes the writers assume that Bayrou, as a centrist candidate, placed greater emphasis on French national integrity and unity.

From the four examples above, the writers believe that Le Pen, Sarkozy, Royal, and Bayrou use different ethos émotif during their campaigns. Le Pen seek to discredit his political opponents, Sarkozy refers to French history, Royal emphasized her personal sentiments, while Bayrou underscores collective sentiments. That is why the writers conclude that in presenting and elucidating their concepts of national identity to gain public support, these candidates apply different ethos émotif. While using specific elements of communication, the candidates also create interactional situations and participated in verbal exchanges. These can be called as "political spectacles" or "political performances." They are prominent phenomena in contemporary society.

It is undeaniable that media contribute significantly to the creation of such "political spectacles." Through media, candidates not only transmit information, but also create an image of themselves in the minds of their audience (Bhatia, 2006; Diakopoulos \& Naaman, 2011; Kinsey, 1993; Pinto-Coelho et al., 2019). The media can also be used as a means of determining whether this "spectacle" is successful or not. The candidates take the media as a political stage, and use them to create meaning. Their speeches enable them to create an image of themselves that suits their political goals (Bennet, 2012; Entman, 2007; Golshan, 2016; Scollon, 1998). This will be further explored in this study. What discourse construction strategies did four presidential candidates (Sarkozy, Royal, Bayrou, and Le Pen) use? How did they interact with the public when conveying their political messages? How did they gain public support for their political plans? What 
role did the media play in determining the major issues of the election? These questions will be answered through this study. First, however, it is necessary to outline the elements that influence the construction of the ethos émotif in political discourse; this will be done in the following section.

\section{Participant Identity, Space, Time, and Goal}

The communication between politicians and the public occurs within a space of interaction and discourse exchange. When presidential candidates deliver their speech, for example, they present a political discourse to the audience (the public). Presidential candidates seek to gain public support for their programs. To do so, they must know to whom they are speaking (i.e., their audience). This may be done by determining the relationship between the speaker and audience, by defining the role of each participant, or by using specific verbal utterances to create a situation where their goals are materialized. As such, to understand the construction of discourse it is necessary to consider participants (who is speaking to whom), space and time (where and when), and goals (for what purpose) (De Stefani \& Horlacher, 2017; Kern, 2015; Linell, 2009; Norris, 2011; Picard, 1992). These elements will be defined further below.

In the interactive space of communication, participants are expected to listen to each other, to express themselves, and to react spontaneously. Hence, participants are marked by their identities and roles. These identities and roles are determined by the participants' individual positions within the discursive community, as their positions will inform their behavior. Although an individual's behavior may be consistent within his or her discursive community, that individual may also evolve or adapt within other communities (Benwell \& Stokoe, 2006; Burke, 2004; Galissot, 1987; Norris, 2011). Thus, individuals' identity accommodates their diverse status and roles. This is why, in politics, a politician may hold several positions or status, as well as the duties and functions inherent to them. For example, it is possible for a politician to simultaneously be a government minister and a presidential or legislative candidate, and to assume specific duties and functions at different times and in different places. The construction of participants' identities, thus, occurs within a spatio-temporal dimension, as identity is constructed within the social space of the discursive community (Benwell \& Stokoe, 2006; KerbratOrrechionni, 1990; Kern, 2015; Picard, 1992).

The spatial dimension is highly influential in interactional situations, as participants will interact with each other in different ways based on their social disposition. The spatial dimension is rooted in the understanding that individual's body does not stop with the skin, but surrounded by a pericorporeal space, a personal space in which others may not enter (Stébé, 2008, p. 43). On the one hand, individuals mark and personalize the space they occupy. On the other hand, interpersonal interactions are informed by the physical distance between individuals, as well as factors such as their gender and physical situation. In political communications, politicians behave differently during televised debates and public speeches. As speakers, politicians adopt specific linguistic tendencies depending on where they are and to whom they are speaking. As such, the writers of this article argue that this concept of space is not only limited to "physical" space, but also includes the spaces manifested in speakers' interpersonal interactions with others. In other words, space includes not only the place or location where interactions occur, but also the one in which participants exchange their ideologies (Dumitrescu, 2010; Gbadegesin \& Onanuga, 2018; Kissas, 2017).

Aside from their spatial dimensions, participants' interactions must also be understood based on their temporal characteristics. In face-to-face or direct interactions, participants are involved at the same time, while in indirect interactions participants may be involved at the same time, or they may be involved at different times. This temporal dimension may be a specific moment, such as when speakers and audience interact (i.e. in exchanging greetings), or involve a specific period that determines the interactions between speakers and audience. In this study, which focuses on political speeches during the 2007 French presidential campaign, participants are identified solely in terms of specific moments. The construction of temporality involves three specific moments: présent ("present"), passé ("past"), and futur ("future"). Utterances that refer to the "present" moment indicate that speakers refer to habitual or current events, while utterances that refer to the "past" indicate that speakers are referring to things that have already happened. The writers of this article assume that the "past" can be used to create specific images and identities for speakers. By relying on "past" experiences, speakers can make arguments that promote their specific ideals and images. Utterances may also refer to the "future," identifying specific goals that have not yet been realized (Kaempfer \& Micheli, 2005; Norris, 2011).

According to Kerbrat-Orrechionni (1990, p. 127), interactions may have two types of goals: external goals and internal goals. Interactions with external goals are generally oriented towards specific purposes or obtaining certain things, such as goods or 
information. Participants, thus, have a reason for speaking with each other. Meanwhile, in interactions with internal goals, participants speak to confirm and maintain their social bonds and relationships. In other words, participants speak with each other to achieve a shared sense of satisfaction. These three elements that constitute the ethos émotif - identity, space/time, and goal-were very important for the candidates in the 2007 French presidential election and enabled them to influence the public (Auchlin, 2000; Maingueneau, $2014 b$ ). This was proven by significant voice acquisition from the four presidential candidates comparing to other candidates. The four candidates, which becomes the focus of this article, obtained more than $10 \%$ of the shares of votes, while others only obtained $1-4 \%$. Through their speeches, these candidates sought to gain sympathy from their audience. As such, the candidates implemented an interactional approach as part of their communication strategies.

\section{Use of Pronouns}

Recognizing the three elements discussed above (participant identity, space/time, and goal), the writers assume that the speaker occupies a special place in the construction of the ethos émotif. When "I" am talking about a certain situation (past, present, or future), then the ideas contained within "my" discourse will differ from those contained within "your" discourse. This shows that the moment when discourse is produced will always influence it, and the speaker will always serve as the "subject" of an utterance through a process of subjectification. As such, pronouns such as "me" and "you" are fundamental elements of ethos émotif construction. "I" or "me" lies at the center of the speech act, taking a role not only as the initiator of the speech act or the conveyer of information, but also as an individual connected to the audience ("you"). Using the software LEXICO3, the researcher examined the extent to which the pronoun "I" (je) was used in four candidates' speeches during the 2007 French presidential election. For the corpus, 12 speeches (3 for each candidate) delivered between March 2006 and May 2007 were used. The figure can be seen below:

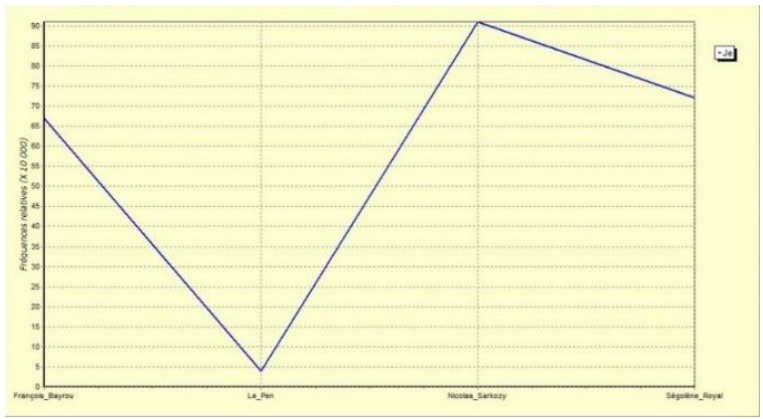

Figure 1. Pronoun 'I'. Source: constructed by the authors from LEXICO analysis.
From this figure, it is clear that Nicolas Sarkozy used the pronoun "I" more frequently than Ségolène Royal, Jean Marie Le-Pen, and François Bayrou. The researcher assumes that the candidate used this pronoun to indicate his own subjectivity in utterances that referred to himself. Aside from using the firstperson singular pronoun "I," which emphasized their own subjectivity, the candidates also referred to themselves using the first-person plural pronoun "we" (nous). This pronoun was used by candidates not to aggrandize themselves and the programs they planned to initiate as president (i.e., as in the "royal we"), but rather to embrace their audiences and show greater familiarity than possible with the pronoun "I." Each candidate presented an interesting ethos émotif through their use of the pronoun "we," as seen in the following table 1 .

Table 1. Frequency of the pronoun nous 'we'. Source: constructed by the authors from LEXICO analysis

\begin{tabular}{|c|c|c|}
\hline Candidate & $\begin{array}{l}\text { Frequency of } \\
\text { the pronoun } \\
\text { "we" (nous) }\end{array}$ & Example Sentence \\
\hline $\begin{array}{l}\text { François } \\
\text { Bayrou }\end{array}$ & 48 & $\begin{array}{l}\text { Nous sommes une nation debout, } \\
\text { nous sommes une nation fière d'elle- } \\
\text { même. Nous sommes une nation } \\
\text { équilibrée. Nous aimons l'équilibre } \\
\text { de la France et ses valeurs, ses } \\
\text { valeurs républicaines. Nous aimons } \\
\text { que ses valeurs républicaines soient } \\
\text { des valeurs qui nous rassemblent et } \\
\text { pas des valeurs qui nous opposent. }\end{array}$ \\
\hline $\begin{array}{l}\text { Marine Le } \\
\text { Pen }\end{array}$ & 5 & $\begin{array}{l}\text { Nous réserverons l'ensemble des } \\
\text { aides sociales, des logements } \\
\text { sociaux aux Français, à tous les } \\
\text { Français mais seulement aux } \\
\text { Français par l'application de la } \\
\text { préférence nationale }\end{array}$ \\
\hline $\begin{array}{l}\text { Nicolas } \\
\text { Sarkozy }\end{array}$ & 22 & $\begin{array}{l}\text { Nous devons aider les organisations } \\
\text { syndicales à mieux représenter le } \\
\text { monde des salariés. Il faut pour cela } \\
\text { instaurer davantage de démocratie } \\
\text { dans les élections professionnelles. } \\
\text { Je n'ai jamais compris le maintien } \\
\text { de la règle archaïque qui donne le } \\
\text { monopole de la présentation des } \\
\text { candidats au premier tour des } \\
\text { élections aux } 5 \text { grandes centrales } \\
\text { syndicales issues de la guerre }\end{array}$ \\
\hline $\begin{array}{l}\text { Ségolène } \\
\text { Royal }\end{array}$ & 28 & $\begin{array}{l}\text { Nous pouvons surmonter la crise de } \\
\text { confiance entre nos concitoyens et } \\
\text { leur agriculture, née des crises } \\
\text { alimentaires et des abus d'engrais et } \\
\text { de pesticides. Je veux redonner aux } \\
\text { agriculteurs la fierté de leur métier } \\
\text { Il faut } \\
\text { aujourd'hui produire autrement: la } \\
\text { qualité doit primer sur la quantité; } \\
\text { l'environnement doit respecté et les } \\
\text { paysages préservés et ceux qui font } \\
\text { ces efforts } \\
\text { doivent recevoir davantage d'aide } \\
\text { car ils agissent pour l'intérêt } \\
\text { général }\end{array}$ \\
\hline
\end{tabular}


François Bayrou used the pronoun "we" to refer to the French state. He presented all French citizens, no matter their background, as being French and having French values. Conversely, the more conservative Le Pen used the pronoun "we" exclusively to refer to the "indigenous" French, thereby marginalizing immigrants and other minorities. Sarkozy and Royal, on the other hand, used the pronoun "we" to refer to the governments they would establish after being elected president.

\section{Appeal to Emotion}

Making appeals to emotion in an effort to win the hearts of one's audience is common in campaign speeches. To gather the support of the public, presidential candidates tend to use a specific lexicon. In the 2007 French presidential election, each candidate used a different approach to appeal to their audience' emotions. These included, for example, using verbs that assert an opinion, using rhetorical questions, using markers of familiarity, using verbs that refer to "working," and using expressions of praise.

\section{Use of Verbs Asserting an Opinion}

In the campaign speeches of the French presidential candidates, expressions of personal opinions and views were common. This strategy was used to voice problems that were perceived as the ones the French people faced, such as education, immigration, terrorism, and the European Union, thereby attracting the audience' attention to said problems and the solutions the candidates offered. In French, opinions may be asserted through the use of specific verbs, including croire (believe), penser (think), savoir (know). Each of the candidates analyzed had different tendencies in using these verbs, as shown in the following graph:

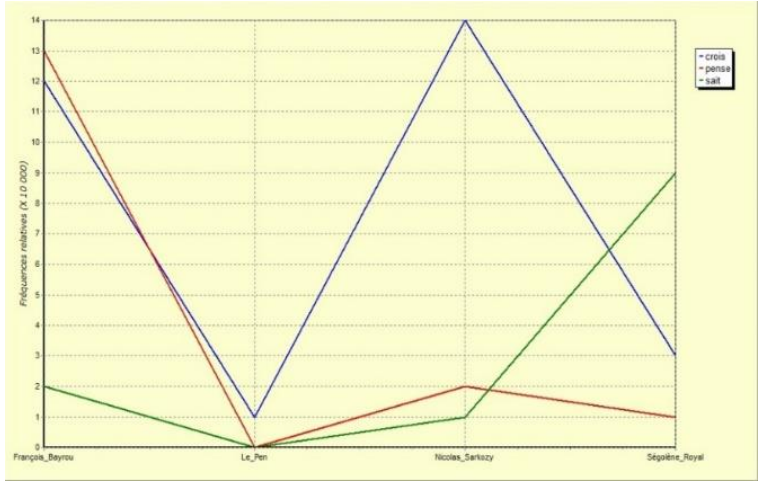

Figure 2. Use of Verbs Asserting an Opinion. Source: constructed by the authors from LEXICO analysis.

From the graph, it can be seen that Le Pen only rarely applied this strategy. This may be attributed to his membership in a rightist party and his focus on the struggles of the French people, an argument supported by Le Pen's frequent use of the word français (French, which is used in his speeches 27 times). Meanwhile, markers of opinions were used most frequently by François Bayrou.

\section{Use of Rhetorical Questions}

The questions used by the candidates in their political speeches were rhetorical, intended not to obtain an answer but rather to support the candidates' arguments. These rhetorical questions were also intended to open the eyes of the French to perceived problems that they may have ignored. Such a strategy was used quite effectively in the candidates' speeches and attempts to persuade their audiences. Of the four presidential candidates analyzed, Royal used rhetorical questions the most often (36 times). Second was Bayrou, who used such questions 33 times, followed by Le Pen (27 times). Sarkozy was the politician who most used this strategy most rarely (only 16 times in three speeches). The number of rhetorical questions asked during candidates' speeches indicates the effectiveness of this method. The effectiveness of this strategy is also indicated by the fact that candidates used a similar number of questions in their speeches; such relative parity was not found in their use of pronouns, markers of familiarity, or use of verbs meaning "work."

\section{Use of Markers of Familiarity}

Politicians frequently attempt to draw the attention of their audiences by using markers of familiarity in their speeches. These utterances are intended to decrease the distance between the politicians and their supporters. In Indonesia, for example, a politician may say "selamat malam rekan-rekan sebangsa dan setanah air" (good evening, fellow Indonesians and compatriots). In French, the markers used by politicians are, among others, ami ("friend"), camarade ("comrade"), and compatriote ("compatriot"). These three words were used in the speeches of the French presidential candidates analyzed in this article.

First the word ami ("friend") is used to show a high level of familiarity between politicians and their supporters. This is because the word ami in French is of equal familiarity to the word friend in English. Politicians, seeking to gain the support of their audiences, have thus used the word ami with their audiences to show friendliness and accessibility. Of the four candidates analyzed in this article, François Bayrou and Nicolas Sarkozy were the ones who used this word in their speeches most frequently. This can be attributed to their political backgrounds; Bayrou was backed by a centralist party, while Sarkozy was supported by an open and liberal UDF. 
Second, the word camarade-according to the Larousse dictionary - is most frequently used by communists and socialists. As such, it is not surprising that the term was most commonly used by Sarkozy and Royal, both of whom were supported by socialist parties. The word compatriot, meanwhile, is most frequently used in more formal and conservative contexts. This is reflected in the findings, as compatriot is the most common in the speeches of the ultraconservative Le Pen.

\section{Use of Action Verbs (verbes d'action)}

In campaign speeches, verbes d'action (verbs that refer to an obligation, activity, or work) are used to indicate that a certain problem has yet to be resolved and thus "action" or "work" is necessary to address it. The most common such verbs in French are falloir ("must") and devoir ("must"). Such verbs may also be used to indicate the progress made in a project, most commonly with the word continuer ("continue"). In the speeches of the four presidential candidates discussed here, the word falloir was used more frequently than the word devoir and continuer. This indicates that the candidates had diverse understandings of the problems being faced by the French people, as well as different recommendations for overcoming these problems. Bayrou and Sarkozy were the candidates who most commonly used falloir to gather audience support, suggesting their analysis was more in-depth than that of Le Pen and Royal. The candidates' use of the verbs falloir, devoir, and continuer can be seen in the table below.

Table 2. Use of Action Verbs. Source: constructed by the authors from LEXICO analysis.

\begin{tabular}{lccc}
\hline \multicolumn{1}{c}{ Candidate } & Falloir & Devoir & Continuer \\
\hline François Bayrou & 67 & 32 & 2 \\
Marine Le Pen & 3 & 6 & 4 \\
Nicolas Sarkozy & 45 & 55 & 9 \\
Sègoléne Royal & 20 & 29 & 1 \\
\hline
\end{tabular}

\section{Use of Complimentary Phrases}

Complimentary phrases are used in political speeches to reinforce the emotional connection between the speaker and the audience, thereby increasing the audience's appreciation (and, more importantly, support) for the candidate. These include, for example, "I am happy to be here," "I feel honored to stand before my fellow compatriots," and "I am pleased to be given this opportunity." Such sentences are also used in French-language campaign speeches. Word choice is also similar, as shown by the examples of heureux (happy) and ému (pleased).

In the campaign speeches analyzed for this article, a few examples of complimentary phrases were identified. The candidate who used such phrases most frequently was Bayrou, whose centrist ideology supported the use of such phrases to gain the greatest possible political support from ideologically diverse audiences. Bayrou was the only candidate who attempted to manipulate his audiences through the word ému; this word was not used in any of the other candidates' speeches.

Unlike Bayrou, Sarkozy used the word heureux, which is considered politer and better suited to the formal and serious context of political speeches. Royal only used such a phrase once in her speeches, while Le Pen did not use any complimentary phrases in his speeches. This again shows the diverse means through which candidates sought to obtain the support of the French people. Some considered them a fundamental part of their speeches, while others dismissed them entirely.

\section{French Media Reactions to the Speeches of Presidential Candidates}

The media play a vital role in the election process, providing a means for seeking publicity, for expressing opinions, and for updating information. Minutes or hours after a politician has a campaign event, it may become the main topic of discussion on internet-based and print-media. This, however, has potential consequences. On the one hand, the media can increase the prestige of a politician and expose his or her good deeds. On the other hand, they can expose the mistakes of candidates - to the detriment of the politicians in question (Glazier \& Boydstun, 2012; Kinsey, 1993; Kissas, 2017; Perloff, 2017). The opinions expressed by the French media in covering candidates' speeches are therefore interesting to consider.

Various media seek to provide their perspective of the diverse discourses of the speeches (Cohen et al., 2008; He, 2019; Liu et al., 2005; McGregor, 2019). This article focuses on articles included in the newspapers Le Monde, Figaro, and Liberation. These three media aree chosen for their diverse ideologies. Le Monde is considered politically neutral; Figaro is considered rightist leaning; while Liberation has a leftist orientation.

Le Monde is one of the largest news publications in France. It attempts to provide neutral coverage, as shown by its positive and negative coverage of the speeches of the presidential candidates during the 2007 election. Of the twelve Le Monde articles covering candidates' speeches, seven showed a favorable response while five showed a negative response. This relative parity in positive and negative coverage indicates that Le Monde attempted to be as objective as possible. 
Of the four candidates analyzed, Royal was the most rarely covered by Le Monde. Only two of her three speeches received attention. This distinguished her from the other candidates, whose gestures, speaking abilities, and audiences all received remark. For example, on November 11, 2007, Le Monde did not report the announcement of Royal's candidacy. Instead, it focused on a speech by PS secretary François Hollande. The speeches of three other candidates, however, did receive criticism. For example, in the coverage of Bayrou, Le Monde quoted the President of the Regional Council of Rhône-Alpes, who opined that Bayrou would be unable to bring change: "François Bayrou est le candidat de l'équivoque et de la confusion" qui propose de "tout changer pour ne rien changer", a ironisé Jean-Jack Queyranne, le président de la région Rhône-Alpes (François Bayrou is a confusing and ambiguous candidate, one who promises change but brings nothing, said Jean-Jack Queyranne, the President of the Rhône-Alpes Region) (Le Monde, April 17, 2007). Further negative response to Bayrou's speech was indicated through Le Monde's quotation of the Mayor of Lyon, who said that Bayrou was "out of time," meaning that the programs he offered were ill-suited to the current condition of France.

Le Figaro is a relatively famous French newspaper, with a circulation of 306,737 in 2015, more than Le Monde and Libération. This number indicates its popularity in France. It is known as having a rightist (conservative) ideology. In its responses to the presidential candidates' speeches, Le Figaro attempted to remain neutral. This can be seen, for example, in the relative parity of positive (7) and negative (5) articles. However, given its rightist ideology, it frequently avoided criticizing right-wing parties such as the UMP.This can be seen, for example, in its coverage of the UMP candidate, Sarkozy, which included no direct negative commentary. In fact, it did not cover Sarkozy's speeches at all, focusing instead on his number of supporters, his views on labor and employment issues, and UMP's support for him.

Le Figaro gave a more direct response to leftist parties such as the PS, represented in this article by Ségolène Royal. Its coverage of such candidates tended to be more positive than its coverage of Sarkozy and Le Pen:

Ségolène Royal dit refuser la confusion des valeurs, fatale à la gauche en 2002, et conteste à la droite le concept de rupture. «Le changement, c'est la gauche qui l'incarne. On ne peut pas s'attribuer des valeurs aux quelles on ne correspond pas » (Ségolène Royal rejected the possibility that their values would be compromised, which had had a fatal effect on leftist parties in 2002, and rejected the rightist concept of rupture. "Change, it's the left that will bring it. We cannot bow to values that are not ours") ( $L e$ Figaro, November 20, 2007).

Le Figaro focused more on the PS' points than other parties'. For example, when covering a speech by Royal, Le Figaro discussed her opposition to Sarkozy's idea of rupture.

Libération is another one of the largest national news media in France, following Le Monde and Le Figaro. Despite its center-left ideology, Libération tended to positively cover all of the French presidential candidates. Of the twelve articles identified, nine included positive commentary of these candidates' speeches; however, it did have clear negative responses in its coverage of parties with the opposite ideological orientation. Nonetheless, compared to Le Monde and Le Figaro, Libération indicated its support for all candidates who could bring a better future, without considering their political parties or their ideological leanings.

Among its positive coverage was that given to JeanMarie Le Pen's speech on globalization and capitalism at Lille. Le Figaro gave considerable praise to Le Pen's speaking style, as well as his support for laborers who lack the capital to improve their lives and who fail to receive living wages. Le Figaro covered Le Pen's speech as follows:

Des accents de Laguiller, donc, mais aussi la volonté manifeste, dans cette région traditionnellement de gauche où le FN s'est installé, de ne pas laisser Nicolas Sarkozy réussir son OPA sur le monde du travail. (With accents of Laguiller, the FN has installed itself in a traditionally leftist area, and sought to ensure that Nicolas Sarkozy cannot revive his OPA program in the workplace) (Libération, February 26, 2007).

In its negative coverage, meanwhile, Libération was starker than Le Monde and Le Figaro. It explicitly challenged the views of political parties and candidates that held different political ideologies, particularly Nikolas Sarkozy. All three of Sarkozy's speeches discussed here were viewed negatively by Libération. For example, in covering Sarkozy's meeting with Dominique de Villepin to discuss the CPE, it reported : Le président de l'UMP est sur le fil du rasoir depuis le début de la crise. Il a accordé officiellement son soutien au CPE et s'est affirmé solidaire de Dominique de Villepin. (The president of the UMP has been on a razor's edge since the beginning of this problem. He has officially given his support to the CPE and asserted his solidarity with Dominique de Villepin) (Libération, March 31, 2006). 


\section{CONCLUSION}

The discussion above shows that the candidates who contested the 2007 French presidential election used the ethos émotif in communicating with the public and the media, thereby constructing a positive image of themselves and their behavior. In other words, they applied specific strategies to appeal to the emotion of their audiences, to gain their audience' support for their statements and policies, and to emphasize their moral superiority. This not only require metalinguistic competencies, but also meta-pragmatic ones. In a political discourse, participants - being influenced by their ideologies, concepts, and cultures - have their own preferences for linguistic forms and expressions.

In the production of political discourse, metapragmatics has two key functions. First, it determines the effectiveness of discourse. If a political discourse does not create ambiguity, it may be seen as effective. To promote effective discourse, speakers must understand the identities of their audience and work together with them. Second, to understand their discursive and social contexts, speakers must understand applicable sociolinguistic standards and formulate their discourse in a way that can be accepted by their audiences. They must not only understand the linguistic standards that enable their audience understand and accept their speeches, but also conform to the specific social and cultural standards of their situations.

Thus, in the writers' opinion, speakers must consider several points before expressing their views. First, speakers must determine the identity (or identities) of their speech partners. Second, they must be capable of using language that is appropriate for their discursive context and promotes discursive legitimacy. Third, they must recognize and honor their speech partners' socio-cultural communication norms. Finally, they must ensure the discourses they create can be easily understood by their speech partners, thereby avoiding misunderstandings.

This article does not aim to critize 'four' of the France presidential candidates in 2007. Instead, it explains the relevance of language use and political discourse and ethos émotif construction strategy in sociopolitical context. At the theoretical level, it exposes national identity problems through discourse analysis theory. At the practical level, it offers an interpretative synthesis that can become an instrument or model of political discourse analysis.

\section{REFERENCES}

Aeschmann, M. (2008). L'ordre et l'autorité dans le discours des candidats à l'élection présidentielle française de 2007: une étude de contenu [Order and authority in 2007 French presidential election's discourse: a content study]. Euryopa Collection 55. Geneva: European Institute of the University of Geneva.

Artufel, C. (2007). Nicolas Sarkozy, ou la communication politique en action [Nicolas Sarkozy, or political communication in action]. La Decouverte, 52, 45-56.

Auchlin, A. (2000). Ethos et expérience du discours [Ethos and experience of discourse]. In M. Wauthion \& A. C. Simon (Eds.), Politesse et ideologie: Rencontres de pragmatique et de rhetorique conversationnelles [Politeness and ideology: The encounter of pragmatics and conversational rhetoric] (pp. 75-93). Louvain-laNeuve: Peeters.

Baider, F., \& Constantinou, M. (2015). Jean-Marie Le Pen vs. Marine Le Pen: Un "ethos émotif" différent'? [Jean-Marie Le Pen vs. Marine Le Pen: Different "ethos émotif?"]. Studia Romanica Posnaniensia, 42(4), 3-19. doi: 10.14746/ strop.2015.424.001

Barou, J. (2014). Integration of immigrants in France: A historical perspective. Identities, 21(6), 642657.

Barthes, R. (1970). L'ancienne rhétorique [Ancient Rhetoric]. Communications, 16, 172-223.

Bennet, W. L. (2012). The Personalization of Politics: Political Identity, Social Media, and Changing Patterns of Participation. The Annals of The American Academy, 644, 20-39. doi: 10.1177/ 0002716212451428.

Benwell, B., \& Stokoe, E. (2006). Discourse and Identity. Edinburg: Edinburg University Press.

Bhatia, A. (2006). Critical discourse analysis of political press conferences. Discourse and Society, 17(2), 173-203. doi: 10.1177/09579265 06058057.

Bowen, J. R. (2004). Beyond migration: Islam as a transnational public space. Journal of Ethnic and Migration Studies, 30(5), 879-894. doi: 10.1080/ 1369183042000245598.

Burke, P. J. (2004). Identities and social structure: The 2003 Cooley-Mead Award address. Social Psychology Quarterly, 67(1), 5-15. doi: 10.1177/ 019027250406700103.

Cohen, J., Tsfati, Y., \& Sheafer, T. (2008). The influence of presumed media influence in politics: Do politicians' perceptions of media power matter? Public Opinion Quarterly, 72(2), 331344.

Coulomb-Gully, M. (2009). Présidentielle 2007. Médias, genre et politique [2007 presidential election: Media, genre, and politics]. [Special Issue: Présidentielle 2007: Scènes de genre (2007 presidential election: Genre Scenes)]. Mots: Les Langages du Politique, 90, 5-11. 
De Stefani, E., \& Horlacher, A.-S. (2017). Une étude interactionnelle de la grammaire: la dislocation à droite évaluative dans la parole-en-interaction [An interactional approach to grammar: Evaluative right-dislocations in talk-in-interaction]. Revue française de linguistique appliquée, 22(2), 15-32. doi: 10.3917/rfla.222.0015.

Dennison, J., \& Talò, T. (2017). Explaining attitudes to immigration in France. EUI Working Paper RSCAS 2017/25. Fisole: European University Institute, Robert Schuman Centre for Advanced Studies, Migration Policy Centre.

Diakopoulos, N., \& Naaman, M. (2011). Towards quality discourse in online news comments. Proceedings of the ACM Conference on Computer Supported Cooperative Work, CSCW. doi: $10.1145 / 1958824.1958844$

Dolez, B., \& Laurent, A. (2007). Une primaire à la française : la désignation de Ségolène Royal par le parti socialiste [A French primary: the designation of Ségolène Royal by the socialist party]. Revue Française de Science Politique, 57(2), 133-161.

Dumitrescu, D. (2010). Know me, love me, fear me: The anatomy of candidate poster designs in the 2007 French legislative elections. Political Communication, 27(1), 20-43.

Entman, R. (2007). Framing bias: Media in the distribution of power. Journal of Communication, 57, 163-173.

Galissot, R. (1987). Sous l'identité, le procès d'identification [On identity, the process of identification]. L'homme et la société, 83, 12-27.

Gbadegesin, V. O., \& Onanuga, P. A. (2018). The enactment of ideology and self-presentation in political campaign videos of the 2015 general election in Nigeria. Discourse, Context and Media, 28, 121-130. doi: 10.1016/j.dcm.2018. 11.002

Glazier, R. A., \& Boydstun, A. E. (2012). The president, the press, and the war: A tale of two framing Agendas. Political Communication, 29, 428446. doi: 10.1080/10584609.2012.721870.

Golshan, T. (2016). Donald Trump's strange speaking style, as explained by linguists. https://www.vox. com/2016/8/18/12423688/donald-trump-speechstyle-explained-by-linguists.

Hainsworth, P. (2004). The extreme right in France: the rise and rise of Jean-Marie Le Pen's Front National. Representation, 40(2), 101-114. doi: 10.1080/00344890408523253

He, J. (2019). Two-layer reading positions in comments on online news discourse about China. Discourse and Communication, 13(5), 473-496. doi: 10.1177/1750481319856206.

Kaempfer, J. \& Micheli, R. (2005). La temporalité narrative: Méthodes et problèmes [Narrative temporality: Methods and problems]. Geneva: Dept of Modern France, University of Geneva.

Kerbrat-Orrechionni, C. (1990). Les interactions verbales [Verbal interactions]. Paris: Armand Colin.

Kern, R. (2015). Language, Literacy, and Technology. Cambridge: Cambride Univeristy Press. doi: 10.1017/CBO978113956770.

Kinsey, D. (1993). Book review: The Reasoning Voter: Communication and Persuasion in Presidential Campaigns. Political Psychology, 14(3), 569-571. doi: 10.2307/3791718.

Kissas, A. (2017). Ideology in the age of mediatized politics: From 'belief systems' to the re-contextualizing principle of discourse. Journal of Political Ideologies, 22(2), 197-215. doi: 10.1080/ 13569317.2017.1306958

Lewis-Beck, M., Nadeau, R., \& Bélanger, E. (2012). French Presidential Elections. New York: Palgrave.

Linell, P. (2009). Rethinking language, mind and world dialogically: Interactional and contextual theories of human sense-making. Charlotte: Information Age Publishing.

Liu, B., Hu, M., \& Cheng, B. (Ed.). (2005). Opinion observer: Analyzing and comparing opinions on the web. In Proceedings of the 14th International World Wide Web conference (WWW-2005).

Maingueneau, D. (2014a). Le recours à l'ethos dans l'analyse du discours littéraire [Ethos Appeal in literary discourse analysis]. Fabula. http://www. fabula.org/colloques/document2424.php, retrieved March $12^{\text {th }}, 2020$

Maingueneau, D. (2014b). Retour critique sur l'éthos [Critical reflection on ethos]. Langage et société, 149(3), 31-48. doi:10.3917//s.149.0031.

Marie, J., Pen, L., National, F., Pen, M. Le, National, F., \& National, F. (2016). L'instrumentalisation de la laïcité contre les droits des femmes. [Political Instrumentalization of Laïcité against Women's Rights].

Martigny, V. (2009). Le débat autour de l'identité nationale dans la campagne présidentielle 2007: Quelle rupture? [The debate over national identity in the 2007 presidential campaign: What rupture?]. French Politics, Culture and Society, 27(1), 23-42.

Mayaffre, D., \& Scholz, R. (2017). Constructing 'the French People' - On Sarkozy's Populism. Journal of Language and Politics, 16(5), 683-705. doi: 10.1075/jlp.15043.dem.

Mayer, N. (2013). From jean-marie to marine le pen: Electoral change on the far right. Parliamentary Affairs, 66(1), 160-178. doi: 10.1093/pa/gss071

McGregor, S. C. (2019). Social media as public opinion: How journalists use social media to 
represent public opinion. Journalism, 20(8), 1070-1086. doi: 10.1177/1464884919845458.

McKinney, M. S., \& Carlin, D. B. (2004). Political campaign debates. In L. L. Kaid (Ed.) Handbook of political communication research (pp. 203234). Mahwah: Lawrence Erlbaum Associates.

Norris, S. (2011). Identity in (inter)action: Introducing multimodal interaction analysis. Berlin: De Gruyter Mouton.

Perloff, R. M. (2017). The dynamics of persuasion: Communication and attitudes in the 21st century. New York: Routledge.

Picard, D. (1992). De la communication à l'interaction: L'évolution des modèles. [From Communication to Interaction: Evolution of Models]. Communication et Langages, 93, 69-83.

Pinto-Coelho, Z., Carvalho, A., \& Castro Seixas, E. (2019). News discourse and readers' comments: Expanding the range of citizenship positions? Journalism, 20(6), 733-751. doi: 10.1177/1464 884917707595.
Schäffner, C. (Ed.).(1997). Analysing Political Speeches. Philadephia: Multilingual Matters Ltd.

Scollon, R. (1998). Mediated Discourse as Social Interaction: A Study of News Discourse. New York: Longman.

Spire, A. (1999). De l'etranger à l'immigre: La magie sociale d'une categorie statistique [From a foreigner to an immigrant: The social magic in statistical category]. Actes de la Recherche Sciences Sociales, 129, 50-56.

Stébé, J. (2008). Risques et enjeux de l'interaction social [Risks and challenges of social interaction]. Paris: Lavoisier.

Van Dijk, T. (2006). Ideology and discourse analysis. Journal of Political Ideologies, 11(2), 115-140.

Weil, P. (2005). La France et ses étrangers: L'aventure d'une politique de l'immigration de 1938 à nos jours [France and its foreigners: The journey of an immigration policy from 1938 to the present]. Paris: Gallimard. 